\title{
PEMBINAAN MANAJEMEN INTERNET SEHAT DAN AMAN BAGI KELUARGA PADA MASYARAKAT KELURAHAN SEKANAK RAYA
}

\author{
Nora Pitri Nainggolan \\ Universitas Putera Batam (UPB), Batam, Indonesia \\ e-mail: Nora@puterabatam.ac.id \\ Heryenzus \\ Universitas Putera Batam (UPB), Batam, Indonesia \\ e-mail: Heryenzus@puterabatam.ac.id \\ Intan Utnasari \\ Universitas Putera Batam (UPB), Batam, Indonesia \\ e-mail: Intan.utna@puterabatam.ac.id
}

\begin{abstract}
Internet has a positive impact on everyday life, but it can also pose a tremendous threat to families or children. Every parent wants their child not to be trapped into the internet world that tends to be detrimental. Therefore, parents should supervise the activities of children in the internet. This activity was carried out through two meetings, which took place in Sekanak Raya Village where the participants of this devotional activity were the Sekanak Raya community. This devotional activity provides coaching to parents to be able to carry out every stage of managing the use of technology and the internet to be useful in the family including in setting mobile phones so that children cannot open things that are negative, teaching parents to be able to internet healthy with children, teaching parents to be able to supervise children well in the introduction of a healthy internet. Based on the discussion of construction conducted on the Sekanak Raya community, it was concluded as follows: (1).Participants understand about the safe use of smartphones for families; (2).Participants of devotion are able to supervise children in the internet; (3). Participants are able to apply the knowledge obtained in accordance with the material of devotion provided.
\end{abstract}

Keywords- Healthy internet, safe internet, family, community.

\section{PENDAHULUAN}

Pesatnya perkembangan dunia teknologi informasi (IT) atau internet dewasa ini, terkadang belum dibarengi dengan adanya pemahaman terhadap penggunaan internet secara baik dan sehat, khususnya bagi pengguna internet dikalangan keluarga. Internet merupakan salah satu kebutuhan penting manusia baik itu untuk anak-anak maupun orang tua. Karena dengan internet maka orang tua akan bisa mendapatkan informasi yang sangat cepat dan bisa diakses dari mana saja. Maka tak heran apabila perkembangan internet di Indonesia juga mengalami peningkatan yang luar biasa dikarenakan manfaatnya yang sangat banyak. 
Internet memberikan dampak positif untuk kehidupan sehari-hari akan tetapi internet juga bisa memberikan ancaman yang luar biasa baik itu untuk keluarga ataupun anak-anak. Saragih, et al (2021) mengatakan bahwa Peranan orang tua, keluarga, dan orang terdekat sangat siginifikan atas berbagai dampak kemajuan informasi teknologi. Setiap orang tua pasti menginginkan anaknya tidak terjebak ke dalam dunia internet yang cenderung merugikan. Oleh karena itu para orang tua hendaknya mengawasi aktivitas anak dalam berinternet. Kewaspadaan terhadap segala kegiatan anak dalam berselancar di dunia maya menjadi penting dikarenakan sangat beragamnya informasi yang hadir terutama informasi-informasi negatif. Informasi negatif tersebut tidak bisa dicegah namun orang tua hanya bisa menyaringnya baik itu dengan mengingatkan anak ataupun dengan memasang software pengaman di komputer orang tua.

Para orang tua harus cerdas dalam memberikan pendidikan internet positif kepada anak. Orang tua bisa sedikit memberikan kebebasan kepada anak untuk bereksplorasi namun sesekali perlu menemani anak berinternet untuk mencari informasi. Salah satu cara yang baik dalam menanamkan pendidikan internet positif kepada anak adalah dengan memberikan pemahaman yang baik kepada anak. Hal-hal yang baik dan buruk harus orang tua jelaskan kepada anak. Pondasi pertama yang harus dibangun adalah pemahaman akan agama. Dengan pemahaman agama yang baik maka si anak akan lebih mudah orang tua ajari untuk menfilter informasi-informasi yang tidak boleh diakses.

Hal selanjutnya yang perlu orang tua lakukan adalah dengan membangun komunikasi efektif kepada anak. Komunikasi ini sangat penting karena dengan komunikasi yang baik akan membuat anak lebih terbuka kepada orang tua. Diskusi aktif antara orang tua dengan anak akan membangun kedekatan dan tentunya akan membantu mengoptimalkan kecerdasan anak baik itu ketika di sekolah ataupun ketika anak mencari informasi positif di internet. Orang tua hendaknya jangan lengah dikarenakan kesibukkan aktivitasnya sehingga komunikasi kepada anak hanya sangat sedikit sekali.

Hal lain yang bisa orang tua lakukan yaitu dengan memasang parental software atau software pemblokiran. Hal ini bisa sedikit mengerem dan mengendalikan anak dalam mengakses ataupun anak tidak sengaja mengklik informasi negatif. Namun efektivitas alat bantu ini sangatlah minim karena anak bisa saja mengakses dari handphone ataupun anak pergi ke warnet. Oleh karena itu yang menjadi perhatian penuh adalah software yang harus terpasang pada anak orang tua yaitu kepandaian anak dalam memilih dan memilah informasi yang ada di internet. Tapi yang terbaik yaitu mencari solusi agar bisa bermanfaat untuk kedua belah pihak yaitu orang tua dan anak karena pelarangan bukanlah jalan yang terbaik.

Dunia internet memang tidak bisa orang tua bendung, namun yang bisa orang tua lakukan adalah menyiapkan generasi yang siap menghadapi tantangan zaman. Internet merupakan dua mata pisau yang bisa saja melukai ataupun bisa memberikan manfaat untuk anak dan keluarga orang tua.

Adapun permasalahan yang ditemui saat melakukan survey ke lokasi pengabdian adalah: (1) Keadaan ekonomi masyarakat yang belum layak; (2) Pendidikan yang minim; (3) Pengetahuan yang terbatas dalam penggunaan teknologi; (4) Pengetahuan yang terbatas dalam menggunakan dan mengelola internet.

Berdasarkan penjabaran ilmu yang disampaikan, maka dapat diambil sebuah judul untuk pengabdian masyarakat yaitu "Pembinaan Manajemen Internet Sehat Dan Aman Bagi Keluarga di Kelurahan Sekanak Raya". Tentunya kegiatan pengabdian ini memerlukan dukungan dan bantuan dari segenap pihak, baik sivitas akademika Fakultas IImu Sosial dan Humaniora Universitas Putera 
Batam maupun pihak lain atas dasar kebersamaan. Dukungan moral, dan materi akan sangat membantu program ini.

\section{METODE}

Melihat permasalahan yang dihadapi oleh masyarakat Sekanak Raya, maka berikut solusi yang ditawarkan dari kegiatan pengabdian ini:

1. Terkait dengan permasalahan mengenai keadaan ekonomi yang masih belum layak. Maka solusi yang ditawarkan adalah menciptakan lapangan kerja baru melalui kegiatan industri rumahan secara online. Namun kegiatan ini dapat dilakukan setelah masyarakat dapat menguasai penggunaan internet.

2. Terkait dengan tempat tinggal yang belum kotor dan kurang sehat. Maka solusi yang ditawarkan adalah memberikan pengabdian dengan manfaat langsung (melakukan gerakan gotong royong). Namun pada kegiatan pengabdian ini lebih menitikberatkan pada pengabdian dengan manfaat tidak langsung.

3. Terkait dengan masalah pendidikan yang minim dan pengetahuan yang terbatas. Maka solusi yang ditawarkan adalah memberikan pembinaan mengenai pengenalan manajemen internet sehat dan aman bagi keluarga sehingga dapat dimanfaatkan secara maksimal.

Dalam pelaksanaan kegiatan pengabdian kepada masyarakat ini, kegiatan ini dilaksanakan melalui dua kali pertemuan, yang bertempat di Kelurahan Sekanak Raya RT 002/RW 001 dimana yang menjadi peserta kegiatan pengabdian ini adalah masyarakat Sekanak Raya.

Untuk menunjang pembinaan yang dilakukan tersebut agar dapat berjalan dengan lancar, maka berikut peralatan-peralatan yang dibutuhkan oleh tim pengabdi selama kegiatan pengabdian:

1. Laptop

2. Smartphone

3. Slide materi

Untuk metode pelaksanaan kegiatan pembinaan ini, ada beberapa hal yang perlu dilakukan, antara lain:

Tabel 1. Metode Pelaksanaan

\begin{tabular}{|c|c|c|c|c|}
\hline Pertemuan & Permasalahan & Solusi & Metode & Pemateri \\
\hline 1 & $\begin{array}{l}\text { Manajemen } \\
\text { Penggunaan } \\
\text { teknologi dan } \\
\text { Internet }\end{array}$ & $\begin{array}{l}\text { Memberikan pembinaan } \\
\text { tentang bagaimana cara } \\
\text { menggelola penggunaan } \\
\text { teknologi yang baik } \\
\text { didalam keluarga }\end{array}$ & $\begin{array}{l}\text { Pembinaan } \\
\text { dan Diskusi }\end{array}$ & Ketua \\
\hline 2 & $\begin{array}{l}\text { Pengetahuan } \\
\text { yang terbatas } \\
\text { dalam } \\
\text { penggunaan } \\
\text { internet sehat } \\
\text { dan aman } \\
\text { dalam keluarga }\end{array}$ & $\begin{array}{l}\text { Memberikan pembinaan } \\
\text { dan } \\
\text { bagaimana pengajarkan } \\
\text { internet yang bermanfaat } \\
\text { dan aman digunakan untuk } \\
\text { segala usia dalam keluarga }\end{array}$ & $\begin{array}{l}\text { Pembinaan } \\
\text { dan Diskusi }\end{array}$ & Anggota 1 \\
\hline 3 & $\begin{array}{l}\text { Pentingnya Peran } \\
\text { orang tua dalam } \\
\text { pengenalan } \\
\text { internet sehat }\end{array}$ & $\begin{array}{l}\text { Memberikan pembinaan } \\
\text { bagaimana peran orang } \\
\text { tua dalam mengawasi } \\
\text { anak, agar anak } \\
\text { memahami internet sehat }\end{array}$ & $\begin{array}{l}\text { Pembinaan } \\
\text { dan Diskusi }\end{array}$ & Anggota 2 \\
\hline
\end{tabular}




\subsection{Tahapan Review}

Kegiatan Pembinaan pada Masyarakat Sekanak raya RT 002/ RW 001 akan dilakukan evaluasi bersama tim pengabdi, agar diketahui seberapa jauh tingkat keberhasilan dari kegiatan pengabdian ini. Evaluasi kegiatan pengabdian ini dapat dilihat pada tabel berikut:

Tabel 2. Evaluasi dalam Pembinaan

\begin{tabular}{|c|c|c|}
\hline Tujuan & Indikator Ketercapaian & Tolak Ukur \\
\hline $\begin{array}{l}\text { Manajemen } \\
\text { Penggunaan teknologi } \\
\text { dan Internet }\end{array}$ & $\begin{array}{lr}\text { Pemahaman } & \text { dan } \\
\text { Pelaksanaan } & \text { penggelolaan } \\
\text { penggunaan teknologi dan } \\
\text { internet dalam keluarga }\end{array}$ & $\begin{array}{l}\text { Mampu melaksanakan } \\
\text { tiap tahapan dari } \\
\text { pengelolaan } \\
\text { penggunaan teknologi } \\
\text { dan internet agar } \\
\text { bermanfaat } \\
\text { keluarga dalam }\end{array}$ \\
\hline $\begin{array}{l}\text { Pengetahuan yang } \\
\text { terbatas dalam } \\
\text { penggunaan internet } \\
\text { sehat dan aman dalam } \\
\text { keluarga }\end{array}$ & $\begin{array}{lr}\text { Pemahaman } & \text { dan } \\
\text { Pelaksanaan } & \text { Penggunaan } \\
\text { internet sehat dan aman } \\
\text { dalam keluarga }\end{array}$ & $\begin{array}{l}\text { Mampu menerapkan } \\
\text { internet sehat dan aman } \\
\text { dalam keluarga }\end{array}$ \\
\hline $\begin{array}{l}\text { Pentingnya Peran orang } \\
\text { tua dalam pengenalan } \\
\text { internet sehat }\end{array}$ & $\begin{array}{l}\text { Memberikan pembinaan } \\
\text { bagaimana peran orang tua } \\
\text { dalam mengawasi anak, agar } \\
\text { anak memahami internet } \\
\text { sehat }\end{array}$ & $\begin{array}{l}\text { Orang tua mampu } \\
\text { mengawasi anak dengan } \\
\text { baik dalam pengenalan } \\
\text { internet sehat }\end{array}$ \\
\hline
\end{tabular}

\subsection{Keberlanjutan Kegiatan}

Keberlanjutan dari hasil kegiatan pengabdian setelah dilakukan pembinaan ini oleh tim pengabdian ini hendaknya memiliki nilai positif untuk berbagai pihak terutama bagi masyarakat Sekanak Raya RT 002/RW 001.

Adapun keberlanjutan kegiatan ini sebagai berikut:

1. Masyarakat mampu menggelola teknologi dan internet agar dapat bermanfaat bagi keluarga.

2. Masyarakat mampu menggunakan teknologi dan internet untuk meningkatkan pendapatan dengan membuat bisnis online.

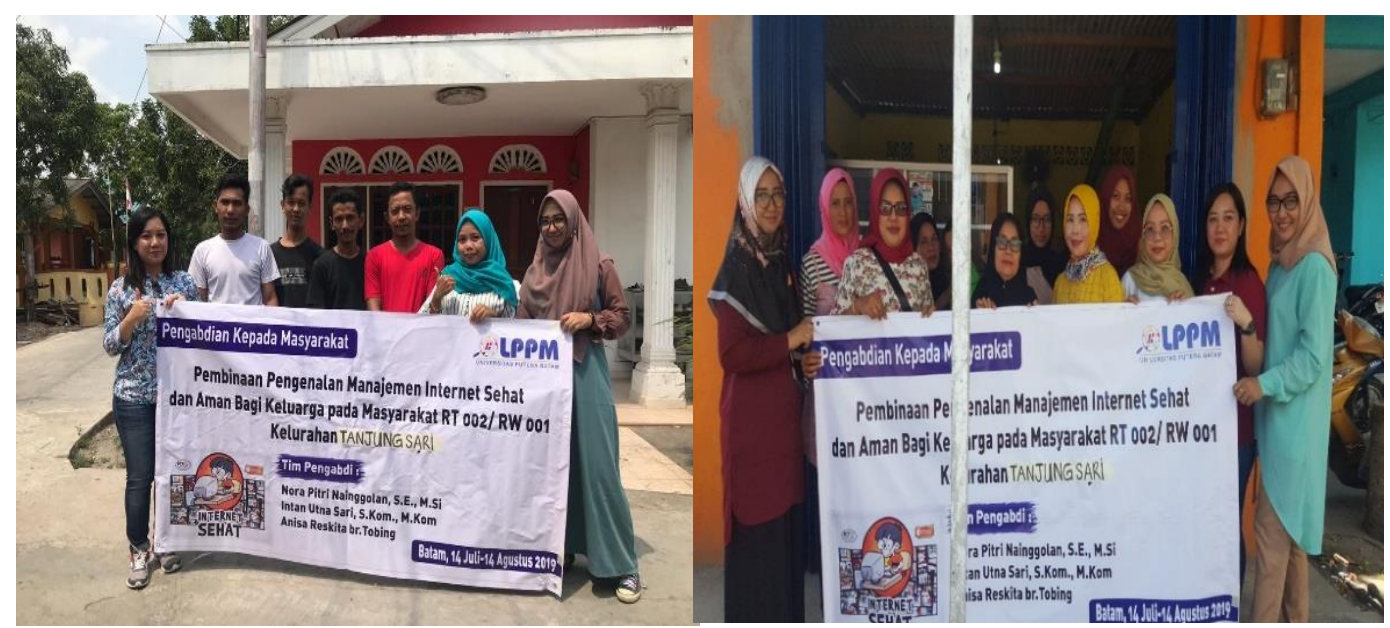

Gambar 1. Pelaksanaan Kegiatan Pengabdian 


\subsection{Hasil Pengabdian}

\section{HASIL DAN PEMBAHASAN}

Berdasarkan pembinaan yang telah dilakukan pada masyarakat Sekanak Raya RT 002/RW 001 telah dapat memberikan dampak yang positif kepada para peserta dan juga kepada tim dosen yang melakukan pembinaan, secara lebih rinci hasil yang dicapai dari pelaksanaan pembinaan tersebut dapat diuraikan antara lain sebagai berikut:

1. Terjalinnya kerjasama antara Universitas Putera Batam dengan masyarakat Sekanak Raya RT 002/RW 001. Melalui kegiatan pengabdian yang dilakukan oleh tim dosen hal ini disambut baik oleh ketua RT maupun masyarakat yang ada disana. Masyarakat merasa diperhatikan dengan adanya pengabdian yang dilakukan oleh tim dosen. Masyarakat berharap pengabdian ini dapat dilakukan secara berkelanjutan.

2. Selama memberikan pembinaan mengenai penggunaan media sosial masyarakat sangat antusias dan bersemangat mengikuti kegiatan. Pengabdi mengharapkan bahwa masyarakat mampu melaksanakan tiap tahapan dari pengelolaan penggunaan teknologi dan internet agar bermanfaat dalam keluarga, mampu menerapkan internet sehat dan aman dalam keluarga, orang tua mampu mengawasi anak dengan baik dalam pengenalan internet sehat.

3. Peserta diberikan pembinaan mengenai pemahaman dan pelaksanaan penggelolaan penggunaan teknologi dan internet dalam keluarga. Hasil dari pembinaan ini kini para orang tua telah memahami bagaimana membuat parental software, sehingga smartphone yang digunakan anakanak dapat membokir situs-situs yang berunsur negatif.

4. Peserta diberikan pembinaan bagaimana peran orang tua dalam mengawasi anak, agar anak memahami internet sehat. Hasil dari pembinaan ini kini orang tua dapat lebih mendekatkan diri dengan anak melalui pertemanan di media sosial agar dapat mengawasi kegiatan anak. Anak diperbolehkan menggunakan smartphone namun untuk anak yang masih dibawah umur hanya boleh membuka smartphone di area yang dekat dengan orang tua sehingga dapat dipantau.

5. Materi pembinaan dari hari pertama sampai dengan hari kedua yang disampaikan sewaktu pengabdian kepada masyarakat Sekanak Raya RT 002/RW 001 yaitu: peran orang tua dalam mendampingi anak berinternet dan hal yang perlu dilakukan untuk mendukung internet sehat.

\subsection{Pembahasan}

Suksesnya kegiatan pembinaan yang diberikan kepada masyarakat Sekanak Raya RT 002/RW 001, telah menjadi kebanggaan tersendiri bagi tim pengabdi. Beberapa hal yang dilaksanakan oleh tim dosen untuk menyukseskan kegiatan pembinaan secara garis besar dapat dijelaskan sebagai berikut:

1. Penyampaian materi pembinaan

2. Mengajarkan orang tua agar mampu melaksanakan tiap tahapan dari pengelolaan penggunaan teknologi dan internet agar bermanfaat dalam keluarga termasuk dalam mensetting handphone agar anak tidak dapat membuka hal-hal yang bersifat negatif

3. Mengajarkan orang tua agar dapat berinternet sehat dengan anak

4. Mengajarkan orang tua agar mampu mengawasi anak dengan baik dalam pengenalan internet sehat

5. Pembuatan laporan pengabdian 
Kegiatan pengabdian yang dilaksanakan di masyarakat Sekanak Raya RT 002/RW 001 memberikan respon positif dan dapat diterima dengan baik oleh masyarakat. Masyarakat antusias mengikuti kegiatan pembinaan yang pengabdi lakukan. Dengan dilaksanakannya kegiatan pembinaan ini, pemahaman masyarakat semakin bertambah dan semakin bersemangat dalam menerapkan internet sehat dan aman bagi keluarga dan sebisa mungkin menyebarkan informasi ini juga ke teman atau saudara yang tidak hadir dalam pembinaan ini. Masyarakat sebagian besar telah memiliki smartphone dan telah memahami bahwa dengan smartphone yang mereka miliki dapat digunakan untuk hal-hal yang positif namun apabila tidak dikelola dengan baik akan dapat menimbulkan hal negatif bagi keluarga.

Selama memberikan pembinaan mengenai manajemen internet sehat dan aman, masyarakat sangat antusias dan bersemangat mengikuti kegiatan. Selain memberi sedikit materi penjelasan tentang internet sehat, pengabdi juga langsung melakukan praktek cara pemblokiran situs tidak aman pada smartphone para orangtua, agar aman saat digunakan anak berinternet. Materi pembinaan dari hari pertama sampai dengan hari kedua yang disampaikan sewaktu pengabdian kepada masyarakat Sekanak Raya yaitu:

\section{Peran Orang Tua dalam Mendampingi Anak Berinternet}

Perkembangan teknologi yang cepat dan canggih pada saat ini setiap orang menggunakan internet sebagai alat untuk menyampaikan informasi, saling tukar informasi, berita, komunikasi, ilmu pengetahuan dan lain sebagainya. Berdasarkan data dari Google.com/adplanner per Mei 2010 telah mencapai 38 juta orang pengguna internet di Indonesia dengan menduduki posisi 5 besar untuk kawasan Asia dengan urutan antara lain Cina, Jepang, India dan Korea Selatan. Menyadari tidak semua konten yang beredar di Internet berbau positif namun banyak juga yang berbau negatif jadi sekarang tinggal bagaimana kita dapat memanfaatkan internet dengan baik dan sehat. Bagi pengguna internet di Indonesia harus aktif dan kreatif mengisi konten lokal sehingga penyalah gunaan internet dapat ditekan sedemikian rupa.

Untuk meminimalisir dampak negatif dari penggunaan intenet bagi anak peran orang tua sangat dibutuhkan. Upaya yang dapat dilakukan agar anak dapat berinternet dengan sehat adalah sebagai berikut:

1. Jika di rumah kita ada anak di bawah umur, gunakan Internet bersama dengan anggota keluarga lain yang lebih dewasa. Tempatkan komputer di ruang keluarga atau di tempat yang mudah diawasi oleh kita. Jika diperlukan, berilah penjadwalan/ pembatasan waktu untuk anak dalam menggunakan Internet.

2. Pelajarilah sarana komunikasi dan kandungan informasi yang ditawarkan oleh Internet, secara bersama dengan anggota keluarga yang lain. Ajukanlah pertanyaan kepada mereka. Dengan banyak bertanya, kita bisa menggali sejauh mana mereka memahami Internet, juga tentang cara menggali infor masi yang bermanfaat.

3. Berikan pengertian kepada seluruh anggota keluarga untuk tidak menanggapi/menjawa setiap e-mail ataupun private chat dari orang yang tak dikenal, termasuk tidak membuka file kiriman (attachment) dari siapapun dan dalam bentuk apapun.

4. Pertegaslah kepada siapapun yang menggunakan Internet di rumah kita untuk tidak memberikan data pribadi/keluarga, alamat rumah/sekolah, nomor telepon, tanggal lahir, password dan data diri lainnya kepada orang yang tak dikenal, ataupun saat mengisi informasi data diri di situs personal, blog ataupun situs lainnya di Internet semisal Facebook.com. 
5. Mintalah kepada anak di bawah umur untuk segera meninggalkan situs yang tidak pantas atau yang membuat mereka tidak nyaman, baik disengaja ataupun tidak sengaja terbuka. Bujuklah agar mereka terbiasa bercerita kepada kita tentang segala sesuatu yang mereka temui di Internet.

6. Tegaskan kepada anak maupun remaja di rumah kita untuk tidak gegabah merencanakan pertemuan langsung (face-to-face) dengan seseorang yang baru mereka kenal di Internet. Jika memang mereka bersikeras untuk tetap bertemu, maka harus dipastikan ada orang dewasa yang menemani dan pertemuannya harus berlangsung di tempat umum/publik.

7. Upaya dan peran orang tua didalam membimbing anaknya menggunakan intenet dapat dibedakan dengan berbagai tingkatan usia misalnya anak yang berusia 2-4 tahun yang dikenalkan kepada anak adalah situs apa saja yang boleh dibuka serta membimbing anak untuk membuka situs secara bersamaan dan mengatakan kepada anak terus berada pada situs yang telah dibuka dan tidak untuk membuka situs lain.

8. Diusia 4-7 tahun yang dilakukan adalah dengan menjelaskan kepada anak terhadap situs-situs yang boleh dikunjungi dan yang bermanfaat bagi ilmu pendidikan boleh dibuka, sedangkan situs-situs yang tidak bermanfaat kita mengajurkan kepada anak untuk tidak membukanya. Kita dapat menyampaikan kepada anak bahwa situs-situs yang melanggar akhlak kalau dibuka akan berdosa.

9. Peran lain yang dilakukan orang tua adalah dengan memasang software penangkal materi-materi yang berbau negatif dari internet. Softwaresofware ini antara lain software parental (filter, monitor dan penjadwalan) seperti K9 Web Protection, Sofware browser anak seperti www.kidrocked.org, software firewall seperti www.zonealam.com.

10. Bagi anak diusia 7-10 tahun, anak sudah mulai mencari informasi dan kehidupan sosial diluar keluarga mereka. rata-rata pada usia ini anak mengingikan kebebasan lebih banyak dari orang tuanya. Di dalam penggunaan internet bagi anak usia ini, tepatkan komputer di ruang terbuka.

lain:

Hal yang bisa di lakukan untuk mendukung akses Internet Sehat antara

1. Hindari Situs Atau Forum yang berbahasa (menjurus ke aktifitas kejahatan internet)

2. Pasang Aplikasi Parental Control bagi Orang tua yang anaknya yang sudah mengenal dan menggunakan internet

3. Berikan Sosialisai Kepada Anak sejak dini soal hal baik dan hal buruk saat menggunakan internet.

4. Gunakan DNS yang bisa memblok situs berbahaya seperti situs Judi, Situs Dewasa yang lainya (Misal DNS Nawala)

5. Pertebal iman dan agama adalah salah satu Firewall utama dalam diri pengguna internet.

6. Aktifitas istilah internet Sehat sebaiknya mulai di terapkan Sejak Dini, disinilah peran orang tua sangat di butuhkan dalam mewujudkan aktifitas

7. Internet Yang sehat, Anak adalah kebanyakan korban dari kejahatan internet, Dampak buruk dari internet ini sendiri bisa merubah psikologis anak, anak belum bisa menentukan baik buruknya suatu aktifitas yang berada di sekitarnya termasuk kejahatan internet itu sendiri.

8. Sebaiknya ketika mengakses internet, orang tua juga ikut dalam pengawasan saat anak sedang surfing di internet. 
9. Saat menggunakan internet, baiknya tidak menggunakannya terlalu lama, agar tidak menimbulkan kecanduan yang bisa mengubah pola hidup yang awalnya melakukan aktifitas - aktifitas positif, kini menjadi terlalu kecanduan dengan hal - hal yang berhubungan dengan internet.

Google Indonesia memberikan beberapa tips untuk keluarga Indonesia dalam menciptakan kebiasaan digital yang sehat sehingga tidak jatuh ke perangkap misinformasi dan tetap aman saat online.

1. Berikan contoh yang baik dan pastikan diri Anda tetap aman. Menurut Veronica Utami, Direktur Marketing YouTube \& NBU untuk Indonesia, Filipina, dan Asia Tenggara di Google, keamanan keluarga dimulai dari diri kita sendiri. Kalau kita sebagai orang tua atau orang yang lebih dewasa tidak mengerti bagaimana menjaga diri kita, lalu bagaimana kita akan memberi contoh yang baik pada anak-anak kita. Maka orang tua perlu belajar bagaimana menjaga keamanannya saat berinternet, sehingga nantinya bisa memberikan contoh dan membangun kebiasaan digital yang sehat untuk anak-anak dan keluarganya, seperti dengan:

$>$ Memilih sandi (password) yang kuat dan sulit ditebak, khususnya untuk akun Google Anda, guna melindungi diri Anda di internet. Atau cara terbaru dengan mengautentikasi identitas Anda dan membangun perlindungan berlapis ke dalam akun Google Anda, seperti pendaftaran otomatis pada verifikasi 2 langkah.

$>$ Meningkatkan fitur Password Manager yang terpasang langsung di Chrome, Android, dan kini iOS, untuk membantu Anda membuat, mengingat, menyimpan, dan mengisi sandi otomatis di seluruh web.

2. Bimbing keluarga Anda menemukan konten yang sesuai

Berdasarkan survei yang dirilis oleh tim Trust Research Google bersama orang tua dan anak-anak berusia 18 tahun ke atas di seluruh Asia Pasifik dan Amerika Latin, ditemukan bahwa salah satu kekhawatiran orang tua di Indonesia adalah anak-anak melihat konten yang tidak pantas di internet. Untuk mengatasinya, selain dengan menerapkan komunikasi yang terbuka dalam keluarga, Anda bisa memanfaatkan sejumlah fitur keamanan keluarga yang dapat digunakan orang tua untuk membantu menjaga anakanak dari konten yang mungkin tidak sesuai dengan usia mereka.

$>$ Sebagai contoh, SafeSearch di Google yang membantu memfilter konten eksplisit di hasil penelusuran, baik gambar, video, dan situs web, hingga kontrol orang tua yang tersedia di YouTube Kids yang memungkinkan orang tua untuk hanya menampilkan video yang disetujui atau memilih konten yang sesuai berdasarkan usia anak.

$>$ Ada pula Family Link yang memungkinkan orang tua untuk mengawasi waktu penggunaan perangkat dan membatasi akses harian, mengelola akun Google mereka, dan memahami dengan lebih baik perilaku anak saat menjelajahi internet.

> Selain itu, yang terbaru, Anda bisa memanfaatkan tab "Kids" (Anak-Anak) di Google Play. Tab khusus ini berisi aplikasi yang telah ditinjau oleh pengajar dan memiliki konten berkualitas tinggi ditandai "disetujui pengajar". Kerangka penilaiannya untuk aplikasi dan konten dapat tampil di tab ini dikembangkan melalui konsultasi dengan penilai lokal di Indonesia dan fakultas dari Harvard Graduate School of Education dan Georgetown University.

3. Jangan terjebak perangkap misinformasi

Tak dimungkiri bahwa sulit sekali untuk menghindari begitu banyaknya 
informasi dan klaim yang tersebar di internet atau di media sosial, serta sulit untuk menentukan mana berita yang benar dan yang tidak, terutama jika Anda belum dilatih untuk mencarinya. Maka saat Anda pertama kali menerima informasi, biasakan diri untuk mengecek faktanya supaya dapat membedakan misinformasi di internet. Misalnya dengan memeriksa apakah gambar digunakan dalam konteks yang tepat. Karena sebuah gambar juga dapat diambil di luar konteks atau diedit untuk menyesatkan orang yang melihatnya. Anda bisa melakukan penelusuran menggunakan gambar dengan mengklik kanan pada gambar atau foto dan pilih "Telusuri gambar ini di Google".

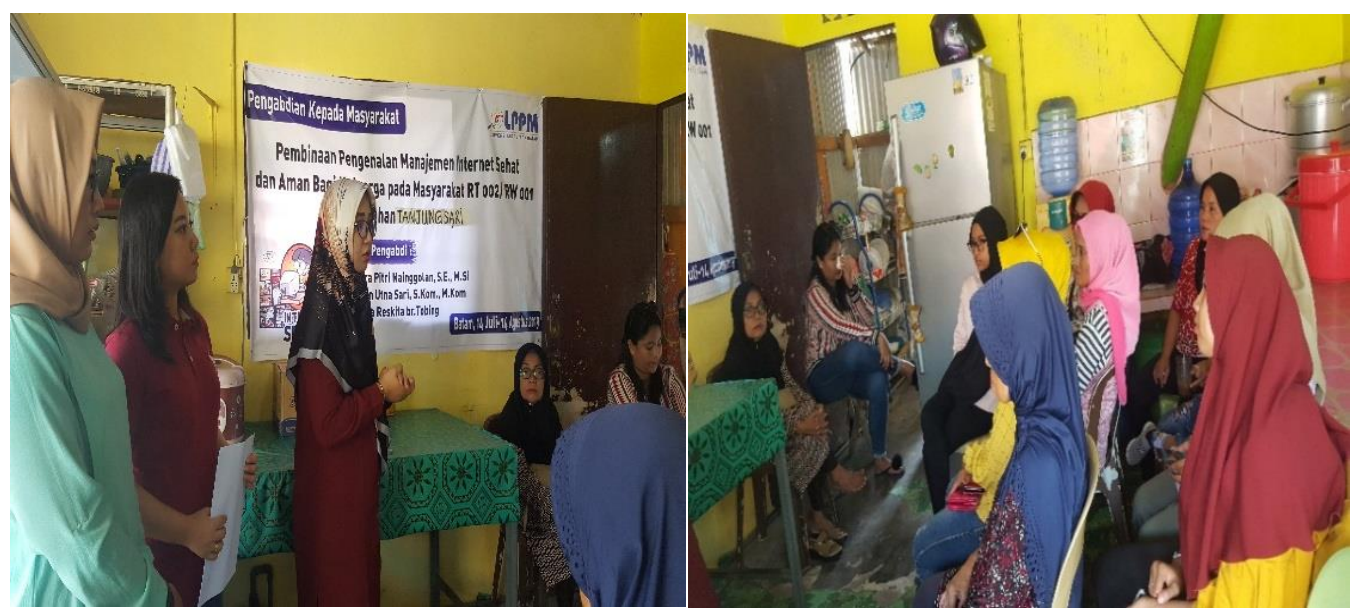

Gambar 2. Foto Pengabdi memberikan pembinaan

\section{KESIMPULAN}

Berdasarkan pembahasan pembinaan yang dilakukan pada masyarakat

Sekanak Raya RT 002/RW 001, maka disimpulkan sebagai berikut:

1. Peserta memahami mengenai penggunaan smartphone dengan aman untuk keluarga

2. Peserta pengabdian mampu mengawasi anak dalam berinternet

3. Peserta mampu menerapkan ilmu yang didapat sesuai dengan materi pengabdian yang diberikan.

\section{SARAN}

Berdasarkan simpulan di atas, maka disarankan sebagai berikut:

1. Masyarakat Sekanak Raya RT 002/RW 001 disarankan dapat meningkatkan semangat mereka untuk tetap dapat mengawasi anak dalam berinternet

2. Masyarakat Sekanak Raya RT 002/RW 001 mencari sebanyak-banyaknya infomasi tentang media sosial yang dimiliki anak, menjalin pertemanan dan memantau aktifitas anak agar anak terhindar dari hal negatif.

3. Masyarakat Sekanak raya RT 002/ RW 001 disarankan tetap bersama anak sewaktu anak menggunakan smartphone terutama anak yang masih dibawah 10 tahun. 


\section{UCAPAN TERIMA KASIH}

Penulis mengucapkan terima kasih kepada Universitas Putera Batam atas kesempatan yang diberikan untuk melakukan pengabdian in. Penulis juga mengucapkan terima kasih kepada tim pengabdian yang telah memberi dukungan finansial sehingga terlaksananya pengabdian ini, serta terima kasih kepada masyarakat Sekanak Raya yang telah bersedia memberikan waktunya untuk mengikuti kegiatan pengabdian dengan sambutan yang baik dan semangat yang tinggi.

\section{DAFTAR PUSTAKA}

Winando, Yoga. (2020). E-Commerse, Pengertian, Manfaat, dan Keuntungannya. Internet: https://www.gurupendidikan.co.id/ecommerce/

Saragih, S. P., Svinarky, I., \& Silalahi, M. (2021). Peningkatan Kemampuan Orang Tua Dalam Mengendalikan Anak-Anak Untuk Mengakses Konten Pornografi. Puan Indonesia, 3(1), 73-82. https://doi.org/10.37296/jpi.v3i1.56 Tokopedia. (2020). Cara Membuka Toko. Internet: https://www.tokopedia.com/help

"Internet Sehat Pedoman Berinternet Sehat, Aman, Nyaman Dan Bertanggungjawab"(2017). Ict Watch.

Http://Aqwamrosadi.Staff.Gunadarma.Ac.Id/Downloads/Files/54430/ManajemenTeknologi.Pdf.

Https://Studylibid.Com/Doc/1077400/Manajemen-Teknologi.

Http://Smkioke.Blogspot.Com/2018/02/Pentingnya-Internet-Sehat.Html 